\title{
Economic Cooperation Of The Republic Of Uzbekistan With The Countries Of Central Asia: Formation, Development, And Prospects
}

\author{
Mirzaev Gulom Rizokulovich \\ Doctor Of Philosophy In History (Ph.D.) Researcher At The Military Technical Institute \\ National Guard Of The Republic Of Uzbekistan
}

Journal Website:

http://usajournalshub.c

om/index,php/tajssei

Copyright: Original

content from this work

may be used under the

terms of the creative

commons attributes

4.0 licence.

\section{ABSTRACT}

The issues, formation, development, and prospects of economic cooperation of the Republic of Uzbekistan with the countries of Central Asia are highlighted in this article. This paper analyses the factors influencing the economic cooperation of Uzbekistan with the countries of Central Asia. The role and importance of trade, exchanging goods, and joint ventures in strengthening economic cooperation between the countries of Central Asia are described gradually. As well as this paper studies the activities of joint Commissions for the development of economic relations and the legal framework of interstate economic cooperation. Such areas economic-trade, joint ventures, and transport Logistics, which determine regional economic growth in Uzbekistan, Kazakhstan, Kyrgyzstan, Tajikistan, and Turkmenistan highlighted with examples. The paper determines that the beginning of a new era in the history of relations between the countries of Central Asia in recent years contributes to the development and strengthening of economic cooperation. Conclusions are drawn on the development of economic cooperation between the Republic of Uzbekistan and Central Asian countries, and several proposals are put forward to strengthen economic cooperation.

\section{KEYWORDS}

Republic of Uzbekistan, Central Asia, economic cooperation, trade-economic, joint ventures, foreign policy, Strategy of Actions, Joint Commission, "economic diplomacy", multiplicative, transport logistics.

\section{INTRODUCTION}

Currently, economic reforms in the Republic of Uzbekistan are carried out primarily by various changes taking place in the world, including in the world economy. The strategy chosen by Uzbekistan demonstrates its stability and viability in the conditions of a decline in the pace of development of the world economy after the global crisis. 
According to international experts, the approach to the implementation of economic policy in Uzbekistan is changing. In particular, according to Sun Chjuanji, the director of the Institute of East European, Russian and Central Asia, which falls under the auspices of the Chinese Academy of Social Sciences "market reforms in Uzbekistan have been shown their effectiveness in recent years. They not only gave new impetus to domestic economic growth and structural reforms and accelerated the country's integration into the world economy but also benefited all Central Asian countries. Uzbekistan's policy of strengthening regional cooperation, resolving disputes through negotiations, and reaching an agreement on various important issues is crucially significant in ensuring regional stability and development ${ }^{1}$. This is primarily aimed at increasing the economic activity of the population of the countries in the region, including Uzbekistan, and creating a favorable business environment. In this regard, it is necessary to pay special attention to the trade and economic cooperation of the Republic of Uzbekistan with the countries of Central Asia.

\section{LITERATURE REVIEW}

Cooperation of the Republic of Uzbekistan with the countries of Central Asia, tasks and issues of foreign policy and international relations, issues of economic cooperation reflected in the works of such researchers Nuriddinov E, Alimov R, Babokhodjaeva L, Rakhimov M, Saifullayev D, Abdimuminov O, Mirzaev G, Kushbaev S, Laumulin L, Dzhekshenkulov A, Saryeva L, Iskandarov A, Aksenov D, Jumaly R, Ziyomov N, Nizomov H,

\footnotetext{
1 “Yangi O'zbekiston” gazetasi 2020 yil 5 noyabr', 212-son
}

Dzhamieva $\mathrm{G}^{2}$. At the same time, in the context of recent events taking place in the

2 Nuriddinov E. Respublika Uzbekistan i sovremennie vizovi Sentral'noy Azii. // Obshestvennie nauki v Uzbekistane. T.: 2015. - № 4. - S. 6 - 13.; Alimov R. Sentral'naya Aziya: Obshnost' interesov. T. «Shark» 2005 g.; Babaxodjaeva L. Mejdunarodnoe kul'turno-gumanitarnoe sotrudnichestvo Respubliki Uzbekistan (period nezavisimosti). - Tashkent: Fan, 2011. - 218 s.; Raximov M. Sotrudnichestvo Uzbekistana s zarubejnimi stranami i mejdunarodnimi organizasiyami $\mathrm{v}$ obespechenii stabil'nosti i ustoychivogo razvitiya v Sentral'noy Azii (1991-2010 godi). Avtoref. dis. ... d-ra. ist. nauk. - T.: 2012. 50 s.; Sayfullaev D. O'zbekiston Respublikasi madaniy diplomatiyasining shakllanishi va rivojlanishi. Tarix fanlari dokt (DSc) diss. Avtoref. - Toshkent: O`zMU, 2020. - 97 b; Abdimo'minov O., Raximov M. "O'zbekiston va BMT" munosabatlar tarixi va barqaror rivojlanish omillari. - Toshkent: "Adabiyot uchqunlari”, 2018. -248 b.; Mirzaev G'. O'zbekiston Respublikasi va Turkmaniston hamkorlik aloqalarining shakllanish va rivojlanish tarixi. Tarix fanlari. bo'yicha fals. dokt. (PhD) diss. Avtoref. - T.: 2018. 54 b.; Kushkumbaev S. Sentral'naya Aziya na putyax integrasii: Geopolitika. Etnichnost'. Bezopasnost'. - Almati: Kazakstan, 2002. - 200 s.; Laumulin M. Sentral'naya Aziya v zarubejnoy politologii i mirovoy geopolitike. Tom I: Sentralnaya Aziya i Kazaxstan v sovremennoy politologii. Almati: 2005. 704 s.; Djekshenkulov A. D. Problemi i perspektivi integrasii gosudarstv Sentral'noy Azii v mirovoe soobshestvo. Dis...dokt. polit. nauk. Moskva. 2000. 392 s.; Sarieva L.S. Ukreplenie dvustoronnego sotrudnichestva Kazaxstana i Uzbekistana kak faktor obespecheniya stabil'nosti i razvitiya Sentral'noaziatskogo regiona. // Aktual'ni problemi yekonomiki №10(184), 2016. - S.17-22. [Elektron resurs].; Iskandarov A. I. Integrasionnie prosessi v gosudarstvax Sentral'noy Azii :Na primere Respubliki Tadjikistan i Turkmenistana. Dis...kand. polit. nauk. M.: 2002. - 172 s; Aksenov D. V. Sentral'noaziatskiy makroregion $\mathrm{v}$ novoy sisteme mejdunarodnix otnosheniy. Dis...kand. polit. nauk. M.: 2000. 157 s; Jumali R. Geopolitika Sentral'noy Azii. - Almati: 2006. - 515 s. Djamieva G.N. Istoriya stanovlniya i razvitiya Turkmenistana kak neytral'nogo gosudarstva (1995-2015 gg.). Avtoref...kand. ist. nauk. Dushanbe. 2018. - 25 s; Nizomov $X$. Mustaqillik yillarida O'zbekiston va Tojikiston Respublikalari o'rtasidagi madaniy aloqalar (1991 - 2007 yillar). Tarix fan. nom. dis. ... avtoref. - Toshkent, 2005. - 24 b; Ziyomov N. Rol' 
world, the cooperation between countries in Central Asia, particularly the cooperation of Uzbekistan with the countries in the region are facing new historical challenges, and this requires an appropriate response. It is worth noting that geopolitical and geo-economic factors are the basis for Uzbekistan's interest in economic cooperation with Kazakhstan, Kyrgyzstan, Tajikistan, and Turkmenistan as a structural element of international economic relations in Central Asia. The analysis of these researches serves as a significant component of understanding the existing processes in the region that may occur in the process of formation, the stages of development, and prospects of economic cooperation of the Republic of Uzbekistan with the countries in Central Asia.

The purpose of the study is to find ways of solving the problems of bilateral economic cooperation between the Republic of Uzbekistan and the countries of Central Asia, to create mutually beneficial cooperation mechanisms to ensure stability and global security in the region.

\section{RESULTS}

One of the priorities of the concept of the foreign policy of the Republic of Uzbekistan in the development of interregional integration in Central $\mathrm{Asia}^{3}$. Such a position is considered the priority of the doctrine of the foreign policy of the Central Asian countries. A new

Uzbekistana $\mathrm{v}$ razvitii mejgosudarstvennogo, ekonomicheskogo i kul'turnogo sotrudnichestva stran Sentral'noy Azii (1991-2001 gg.). Dis. ...kand. ist. nauk. - Tashkent, 2002. - S. 133-149.

3 O'zbekiston Respublikasining Tashqi siyosiy faoliyati Konsepsiyasi. 2012 yil 10 sentyabrdagi O`RQ - 330-sonli O‘zbekiston Respublikasi Qonuni bilan tasdiqlangan // $\mathrm{O}^{\prime} z$ bekiston Respublikasi Oliy Majlisi palatalarining Axborotnomasi. 2012/№9/1(1437). - B.13. era in the foreign policy of Uzbekistan on regional cooperation has begun after Shavkat Mirziyoyev came to the power as President of the Republic of Uzbekistan. Attention paid to the dynamics of the development of interstate relations among the countries in the whole region determined by their level of interaction, the implementation of prospective projects in the regional context began to reflect in the struggle of the countries of Central Asia together against internal and external threats. President of Uzbekistan Sh. Mirziyoyev noted, "Today, Uzbekistan considers the region of Central Asia to be as the main priority of its foreign policy. And this is a conscious choice. Being in the heart of Central Asia, Uzbekistan is keenly interested in the region to become a zone of stability, sustainable development, and goodneighborliness. A peaceful and economically prosperous Central Asia is our most important goal and key task ${ }^{4}$.

Therefore, the trade and economic cooperation of Uzbekistan with the countries of Central Asia plays a significant role. The reason for the consideration as the beginning of a new era in the history of relations of Central Asian countries in recent years, significant positive results have been achieved in the interstate relations in a short period. Neighboring countries have opened to each other not only borders but also markets. For the first time since the establishment of newly independent states in the region, neighboring countries established cooperation in the field of industry, mutual investment, and security.

\footnotetext{
${ }^{4} \mathrm{O}$ 'zbekiston Respublikasi Prezidenti Shavkat Mirziyoevning Birlashgan Millatlar Tashkiloti Bosh Assambleyasining 72-sessiyasidagi nutqi. // Xalq so'zi. - 2017. - 20 sent.
} 
It is worth noting that, the Republic of Uzbekistan and the Republic of Kazakhstan are the leading countries in Central Asia in terms of economic, demographic, and military potential, their mutually beneficial bilateral and multilateral cooperation on a large scale beyond their capabilities play a pivotal role in the formation of regional economic structures. These aspects determine the importance and priority of the Kazakh vector in the foreign policy of Uzbekistan, the Uzbek vector in the foreign policy of Kazakhstan.

The summit of the heads of Central Asian countries, which was held for the first time in March 2018 in Astana, the capital of the Republic of Kazakhstan, also serves to strengthen the beginning of a new stage of bilateral relations between the countries of the region. The continuation of cooperation at a new stage has a positive impact on mutual trade and economic results. We can see the growth rate in Uzbekistan's foreign trade turnover with the countries of the region in 2018.

According to the Statistics Committee of the Ministry of National Economy of the Republic of Kazakhstan, the trade volume between Kazakhstan and Uzbekistan in 2015 amounted to 1.67 billion US dollars 5 . This economical indicator is significantly lower than the economic potential of the two countries, and efforts were made to increase the volume of bilateral trade based on economic cooperation agreements to address this problem. As a result, through collaborative

\footnotetext{
${ }^{5}$ Sarieva L.S. Ukreplenie dvustoronnego sotrudnichestva Kazaxstana i Uzbekistana kak faktor obespecheniya stabil'nosti i razvitiya Sentral'noaziatskogo regiona. // Aktual'ni problemi yekonomiki №10(184), 2016. - S.17-22. [Elektron resurs].
}

efforts in 2017, Uzbekistan and Kazakhstan managed to increase bilateral trade turnover to 2 billion US dollars. Also, the delegations of Jizzakh, Tashkent, Syrdarya regions, and the city of Tashkent visited the neighboring country and held very effective meetings. In turn, representatives of South Kazakhstan, Kostanay, Jambyl, Kyzylorda, and East Kazakhstan regions visited Uzbekistan. Such relations serve as the basis for the effective implementation of bilateral and multilateral cooperation $^{6}$. On April 14-15, 2019, at the invitation of the President of the Republic of Uzbekistan Shavkat Mirziyoyev, the President of the Republic of Kazakhstan Kassym -Jomart Tokayev visited Uzbekistan on a state visit. Both sides positively assessed the results of the First Forum of Interregional Cooperation between Uzbekistan and Kazakhstan, held in November 2018 in Shymkent, as well as the First Regional Economic Forum of the Central Asian Countries that took place in March in Tashkent?

At present time, 336 enterprises with the participation of Kazakhstan capital and 16 offices of companies, 199 enterprises established on the territory of Kazakhstan in cooperation with Uzbek businesspersons have been operating. They provide trade, transport and logistics, and other services, as well as construction materials and a wide range of consumer goods ${ }^{8}$. While the total trade turnover with Kazakhstan in 2017 amounted to 1.7 billion US dollars, in 2018 this figure reached 2.6 billion US dollars. "GM Uzbekistan" launched to collect its cars in Kazakhstan. Implementation of the Silk Road

\footnotetext{
${ }^{6}$ Xalq so'zi. -2018 yil -14 mart.

7 Xalq so'zi. - 2019. - 16 aprel'.

${ }^{8}$ Xalq so'zi. - 2019. - 16 aprel'.
} 
visa project to develop regional tourism planned too.

The analysis of the research on the subject indicates that although significant work was carried out in trade and economic cooperation between Uzbekistan and Turkmenistan on trade turnover, it has been determined that trade turnover has decreased in 2014-2016. In other words, the turnover in 2014 was 413.1 million, in 2015 - 319.9 million, in 2016 - 209.0 million dollars ${ }^{9}$. It also determines that the number of joint ventures established based on investments of these countries is significantly less than their capacity (only 11) ${ }^{10}$. This issue was also discussed during the meeting with the President of Turkmenistan, who visited Uzbekistan on April 23-24, 2018. In the meeting, the sides agreed to take measures to increase trade turnover to $\$ 500$ million by 2020. ${ }^{11}$

In 2018, 260 Uzbek-Kazakh ${ }^{12}, 57$ UzbekKyrgyz $^{13}$, and 25 Uzbek-Tajik $^{14}$ joint ventures established in the Republic of Uzbekistan in comparison with other countries of Central Asia. Also, it is necessary to indicate that the signing of a memorandum on the transit and transmission of electricity between the Ministry of Energy of Turkmenistan and the "Uzbekenergo" joint-stock company on May

\footnotetext{
${ }^{9}$ O`zR DSQ JA. 2013 - 2017 (yanv-sent) yillar davomida O‘zbekiston Respublikasi va Turkmaniston davlati o"rtasida tashqi savdo aylanmasi haqida ma'lumot. 1 - varaq.

${ }^{10} \mathrm{O}^{\prime} z R$ DSQ JA. Respublika bo ‘yicha faoliyat ko'rsatayotgan Turkmaniston hamkorligida O'zbekistonda tashkil topgan qo'shma korxonalar ro'yxati. 01.10.2017 y. holatiga. 2 - varaq.

${ }^{11}$ Xalq so'zi. - 2018. -24 apr.

${ }^{12}$ Xalq so'zi. - 2018. - 16 mart.

${ }^{13}$ https://uzreport.news/economy/kolichestvopredpriyatiy-s-inostrannim-kapitalom-V-uzbekistaneprevisilo-5-5-tis (18.03.2018).

${ }^{14}$ Xalq so'zi. - 2018. - 10 mart.
}

20,2017 , undoubtedly played a significant role in the development and strengthening of bilateral cooperation ${ }^{15}$.

Analysis of materials on cooperation between Uzbekistan and the Kyrgyz Republic shows that economic and cultural cooperation in 2000-2015 has developed slowly. The reason for this can be explained by the fact that these countries are limited by economic and social issues on their way of development, as well as the frequent exchange of government in Kyrgyzstan. Deepening bilateral relations in the fields of culture, education, science, art, and tourism, which are part of the cultural and humanitarian relations between the two countries, identified as high-level goals of the two leaders and due to this task, the current relations in this sphere have been consistently developing and the relevant legal framework has been creating. For instance, the visits of the delegation of the Botkent region to Fergana region in May in 2016, and the visits of the Osh city authority to Andijan region on August 10, and the holding of the business forum was another confirmation of the serious approach to establishing regular relations in the border regions, which is one of the factors that play an important role in the increase of mutual trust of our peoples ${ }^{16}$.

We can see in developing trade and economic cooperation steadily and rapidly that significant changes were in the economic cooperation of Uzbekistan and Tajikistan in recent years. An exhibition-fair of Uzbek manufacturers opened on April 17-20, 2017 at the "Poytakht-90" shopping mall in Dushanbe.

\footnotetext{
15 http://kun.uz/news/2017/05/21/savkat-mirzieev-vagurbanguli-berdimuhamedov-imzolagan-uzzatlarnimalardan-iborat (22.05. 2017).

${ }^{16}$ Xalq so'zi, 2017 yil 5 sentyabr'
} 
In the exhibition, 160 manufacturers from different sectors of the industry demonstrated their products. Also, the business forum of the business circles of Tajikistan and Uzbekistan, which held on April 19, 2017, served as an additional platform for strengthening trade and economic relations between the countries and this served to strengthen trade and economic relations, attract investments, establish joint ventures, and raise the indicators of bilateral trade turnover ${ }^{17}$.

By the end of 2017, the total trade turnover amounted to 240 million US dollars. It has considered the highest rate in the last 20 years. The capacity for delivery of goods increased more than 10 times. Transport and services, textile and plastic products, household appliances took the main place ${ }^{18}$. Besides, by 2018, the presence of 39 enterprises of Tajikistan in Uzbekistan, and 8 enterprises of Uzbekistan in Tajikistan indicates that the cooperation is not yet at the level of demand in this area ${ }^{19}$.

On January 10-11, 2018, the Prime Minister of the Republic of Uzbekistan visited Dushanbe, issues serving regional stability along with economic and social issues discussed in the meeting of the intergovernmental commission on trade and Economic Cooperation and delimitation of state borders. As a result, the A-337 international highway opened between Samarkand and Panjikent, and transmission

\footnotetext{
${ }^{17}$ http://kun.uz/news/2017/04/17/dusanbedauzbekiston-masulotlari-kurgazmasi-bulib-utmokda (02.10.2017).

${ }^{18}$ Xalq so'zi. 2018 yil 10 mart.

${ }^{19}$ Xalq so'zi. 2018 yil 18 avgust.
}

points on the Uzbek-Tajik border resumed their operations ${ }^{20}$.

It is necessary to note that these changes do not happen by themselves. Under the leadership of the president, an active foreign policy based on open and mutual trust in relations to the countries of Central Asia and our neighbors was an important foundation in the changes taking place in our region.

Uzbekistan's trade turnover with Central Asian countries has grown at an unprecedented rate. The trade turnover was $\$$ 2.4 billion in 2017 and reached $\$ 5.2$ billion by the end of 2019. In two short years, the growth was 150 percent $^{21}$.

In 2019, about 4 million citizens of neighboring countries visited Uzbekistan at various levels. People's diplomacy, which has been developing rapidly in recent years, plays a crucial role in this. People's diplomacy, in turn, leads to the development of economic diplomacy.

The trade turnover between Tajikistan and Uzbekistan in 2019 increased by $23.4 \%$ compared to 2018 and amounted to $\$ 480$ million. Compared to 2017, this growth was 200\%. The trade turnover with Turkmenistan at the end of 2019 amounted to \$ 540 million. The growth compared to 2017 is 300 percent.

"This trade turnover is not only import, export, but also multiplicative, that is, the creation of new jobs, infrastructure, which in turn will ensure the growth of the living standards of the population. The policy of Uzbekistan with the countries of Central Asia

\footnotetext{
20 Xalq so“zi. 2018 yil 10 mart.

${ }^{21}$ Mustafoev B.R. O‘zbekistonning Markaziy Osiyodagi savdo aylanmasi misli ko'rilmagan darajada o'sgan. // https://kun.uz/91055693
} 
in recent years recognized by many experts and leaders of international organizations"22.

As noted, the investment attractiveness of Central Asia also grew by 32 percent compared to 2017. That is, the total investment in the region in the 2017 year amounted to 24 billion dollars, and then by the end of 2019, this figure reached 35, 9 billion $^{23}$. Because of the efforts carried out by the leadership of Uzbekistan to re-strengthen the cooperation of the countries of the region, the volume of trade turnover of Uzbekistan with Kazakhstan, Kyrgyzstan, Tajikistan, and Turkmenistan increased by almost 3 billion dollars by the end of 2017, that is, by 20 percent. In this regard, the supply of goods increased by one time ${ }^{24}$.

At the same time, the relations between the Republic of Uzbekistan and the countries of Central Asia are entering a new stage. For example, in 2018, the volume of trade turnover between Uzbekistan and Kazakhstan grew by 50 percent and exceeded 3 billion dollars. The mutual trade turnover of Uzbekistan with Kyrgyzstan in 2018 exceeded 481 million dollars, and with Tajikistan exceeded 389 million dollars ${ }^{25}$, and with Turkmenistan, the economic cooperation amounted to 302 million dollars ${ }^{26}$.

The countries of the region considered developing countries with their path of

\footnotetext{
${ }^{22}$ Mustafoev B.R. O‘zbekistonning Markaziy Osiyodagi savdo aylanmasi misli ko'rilmagan darajada o'sgan. // https://kun.uz/91055693

${ }^{23}$ Mustafoev B.R. O‘zbekistonning Markaziy Osiyodagi savdo aylanmasi misli ko'rilmagan darajada o'sgan. // https://kun.uz/91055693

${ }^{24}$ Mirziyoev Sh.M. Xalqimizning roziligi bizning faoliyatimizga berilgan eng oliy bahodir. 2-jild. - T.:

“O'zbekiston” NMIU, 2018. - B. 273.

${ }^{25}$ Xalq so'zi. 2019 yil 30 noyabr'.

${ }^{26}$ Xalq so'zi. 2019 yil 29 noyabr'.
}

progress and developing their foreign policy activities based on such principles as humanity, social justice, creating an environment of security, peace, and tranquility in the region.

According to Sherali Rizoyan, the Tajik expert, in general, favorable conditions are created for the development of Central Asia as a region, but it is necessary to develop scientific approaches to construction, to develop and promote common regional interests that do not contradict the national interests of the countries of Central Asia. The importance of such an approach is explained by the fact that a complete improvement in the relations between the countries of Central Asia can serve to the formation of a new center for global policy. "Therefore, it is necessary to conduct additional, more in-depth studies to identify common peculiarities and common structures of regional interests ${ }^{27}$.

According to the researchers of the leading international company "Boston Consulting Group" (BCG), which advises on business strategy, today the countries of Central Asia have opportunities to change their direction by diversifying the economy of the region towards sectors that do not specialize only in raw materials. This requires investments in infrastructure projects and the development of prospective industries that are not based on raw materials. Continuing and further deepening market reforms, as well as the deepening of inter-regional cooperation considered a prerequisite for improving the investment climate of Central Asia.

\footnotetext{
${ }^{27}$ https://uzanalytics.com/xalqaromunosabat/3830/ (04.05.2019).
} 
The authors of this report, based on their research on the issues of relations of Central Asian countries, noted, five important areas can activate regional cooperation:

1. Development of regional infrastructure. Establishing regional infrastructure is the first and necessary step towards deepening cooperation. The existing infrastructure in the region needs to be significantly improved.

2. Support the cross-border movement of goods, services, people, and capital. Deepening integration in regional trade is the main condition for the development of economic relations between these countries.

3. Harmonization of the legal framework. The experiences of other regions indicate that the harmonization of the legal framework serves to increase investments significantly.

4. Active development of complementarity. Each country in Central Asia has its complementary peculiarities. Instead of competing, countries can achieve more results if they cooperate.

5. Coordinate the strategy of attracting investments. Efforts of countries in the region to attract large amounts of investment alone may be ineffective. Combining active coordination and efforts to attract investors at the general regional level will fit the purposes $^{28}$.

28

https://uzanalytics.com/iqtisodi\%D0\%B5t/4448/?fbcl id=IwAR0WFxZDifzTV-
According to B. Mustafayev, an expert on the issues of cooperation in Central Asia, the opening of the border has stimulated the development of tourism between the regions. For example, the number of tourists visiting the region in 2017 was 19.5 million, while in 2019 this number reached 25.4 million $^{29}$.

Analyzing the issues of economic cooperation of Uzbekistan with the countries of the region, we should pay special attention to transport communications in this regard. Also, the important strategic location of the Central Asian countries requires the rational use of the potential of international transport corridors. Since 2017, railway, air, and Highway flights have been organized, since August 2018 cargo transportation along with the China Kyrgyzstan - Uzbekistan - Afghanistan highway has been launched, which creates wide opportunities for the implementation of new "East-West", "North-South" transport and communication projects.

The proposal of the president of the Republic of Uzbekistan put forward at the 75th session of the United Nations organization on September 23, 2020, also plays a significant role in strengthening economic cooperation and defining the prospects of Central Asian countries. According to Mirziyoyev, the current important strategic task for the Central Asian states is to ensure the deep integration of the region into the global economic, transport, and transit corridors. In this regard, under the auspices of the United Nations, he offers to open the Regional Center

stGWZG81Yq8IEdjJnthNHx9CHKOtHRhCw2eQ9H Le8uQPQ (26.04.2019).

${ }^{29}$ Mustafoev B.R. O'zbekistonning Markaziy Osiyodagi savdo aylanmasi misli ko'rilmagan darajada o'sgan. // https://kun.uz/91055693 
for the development of transport and communication ${ }^{30}$.

A comprehensive improvement of the relations between the countries of Central Asia can serve to the formation of a new center for global policy. "Therefore, it is necessary to conduct additional, in-depth research to identify common peculiarities and common structures of regional interest ${ }^{31}$.

Also, industrial cooperation, further strengthening of trade, and economic relations between the regions, the development of regional tourism are among the priorities.

\section{CONCLUSION}

The economic cooperation of the Republic of Uzbekistan with the countries of Central Asia has gained a new landscape in the years of independence. In particular, in the 2016 year, when Shavkat Mirziyoyev become the President, a new era began for regional economic integration. The economic cooperation of Uzbekistan with Central Asian countries has been steadily strengthening. As a result, the implementation of collaborative projects in the border areas of the two countries marked the formation of a new approach to economic cooperation. The attention of Uzbekistan to the development of relations between the countries of Central Asia in a harmonious, friendly, and mutually beneficial manner serves to mark the prospects of regional economic cooperation. At the same time, we may put forward several proposals on the further development and strengthening of economic cooperation of the

\footnotetext{
${ }^{30} \mathrm{https}: / / \mathrm{www}$. gazeta.uz/uz/2020/09/23/bmt/

31 https://uzanalytics.com/xalqaromunosabat/3830/ (04.05.2019).
}

Republic of Uzbekistan with the countries of Central Asia today and they include:

1. bilateral and multilateral legal documents on economic cooperation of Uzbekistan with Central Asian countries have been signed, monitoring their implementation regularly and adoption of new ones if necessary;

2. to act based on normative documents of international law in economic cooperation, in the use of various political, economic, military, transport, environmental, cross-border rivers in the Central Asian region, in the prevent the accumulation of nationalethnic, cross-border problems;

3. Developing transport and transit capacity further strengthen, expand and deepen the new era of economic cooperation between Central Asian countries, the formation of an effective system of land communications in the region by accelerating railway project along the China-Kyrgyzstan-Uzbekistan multimodal transport corridor.

4. Accelerate the process of digitization of the economy to develop economic cooperation between the countries of Central Asia in response to the pandemic.

5. formation of analytical and regional information group regularly deals with internal and external factors that spoil the strengthening of regional cooperation;

6. The scope of bilateral trade and economic cooperation between the Republic of Uzbekistan and Central Asian countries is extensive. It will fit 
purposes if the intergovernmental Joint Commission on Trade, Economic, Scientific, Technical and Cultural Cooperation holds regular meetings, develops measures to take advantage of untapped opportunities, frequently pays attention to the issues of opening and developing new areas of cooperation.

7. It will be appropriate if the countries of the region develop joint measures for the widespread introduction of information technology in trade and customs clearance.

To sum up, the consistent development of economic cooperation of the Republic of Uzbekistan with the countries of Central Asia, the increase of joint economic projects in the region, the creation of favorable conditions for the development of trade and economic cooperation are important in determining and developing the prospects of Economic Cooperation.

\section{REFERENCES}

1. Mirziyoev Sh.M. Xalqimizning roziligi bizning faoliyatimizga berilgan eng oliy bahodir. 2-jild. - T.: "O'zbekiston” NMIU, 2018. - B. 273.

2. O'zbekiston Respublikasi Prezidenti Shavkat Mirziyoevning Birlashgan Millatlar Tashkiloti Bosh Assambleyasining 72-sessiyasidagi nutqi. // Xalq so'zi. - 2017. - 20 sent.

3. O‘zbekiston Respublikasi Prezidenti Shavkat Mirziyoevning Birlashgan Millatlar Tashkiloti Bosh Assambleyasining 75-sessiyasidagi nutqi.https://www.gazeta.uz/uz/2020/09/ 23/bmt/

4. Mustafoev B.R. O‘zbekistonning Markaziy Osiyodagi savdo aylanmasi misli ko'rilmagan darajada o'sgan. // https://uzreport.news/economy/kolichest vo-predpriyatiy-s-inostrannim-kapitalomv-uzbekistane-previsilo-5-5-tis (18.03.2018).

5. Nuriddinov E. Respublika Uzbekistan $i$ sovremennie vizovi Sentral'noy Azii. // Obshestvennie nauki $\mathrm{v}$ Uzbekistane. T.: 2015. - № 4. - S. 6 - 13.; Alimov R. Sentral'naya Aziya: Obshnost' interesov. T. «Shark» 2005 g. S.36-41.; Babaxodjaeva L. Mejdunarodnoe kul'turnogumanitarnoe sotrudnichestvo Respubliki Uzbekistan (period nezavisimosti). Tashkent: Fan, 2011. - 218 s.; Raximov M. Sotrudnichestvo Uzbekistana S zarubejnimi stranami i mejdunarodnimi organizasiyami v obespechenii stabil'nosti i ustoychivogo razvitiya v Sentral'noy Azii (1991-2010 godi). Avtoref. dis. ... d-ra. ist. nauk. - T.: 2012. 50 s.; Sayfullaev D. O'zbekiston Respublikasi madaniy diplomatiyasining shakllanishi va rivojlanishi. Tarix fanlari dokt (DSc) diss. Avtoref. - Toshkent: O'zMU, 2020. - 97 b; Abdimo'minov O., Raximov $M$. "O‘zbekiston va BMT" munosabatlar tarixi va barqaror rivojlanish omillari. Toshkent: "Adabiyot uchqunlari”, 2018. 248 b.; Mirzaev G'. O’zbekiston Respublikasi va Turkmaniston hamkorlik aloqalarining shakllanish va rivojlanish tarixi. Tarix fanlari. bo'yicha fals. dokt. (PhD) diss. Avtoref. - T.: 2018. 54 b.; Kushkumbaev S. Sentral'naya Aziya na putyax integrasii: Geopolitika. Etnichnost'. Bezopasnost'. - Almati: 
Kazakstan, 2002. - 200 s.; Laumulin M. Sentral'naya Aziya $v$ zarubejnoy politologii i mirovoy geopolitike. Tom I: Sentralnaya Aziya i Kazaxstan v sovremennoy politologii. - Almati: 2005. 704 s.; Djekshenkulov A. D. Problemi i perspektivi integrasii gosudarstv Sentral'noy Azii v mirovoe soobshestvo. Dis...dokt. polit. nauk. Moskva. 2000. 392 s.; Sarieva L.S. Ukreplenie dvustoronnego sotrudnichestva Kazaxstana i Uzbekistana kak faktor obespecheniya stabil'nosti i razvitiya Sentral'noaziatskogo regiona. // Aktual'ni problemi yekonomiki №10(184), 2016. S.17-22. [Elektron resurs].;Iskandarov A. I. Integrasionnie prosessi $v$ gosudarstvax Sentral'noy Azii :Na primere Respubliki Tadjikistan i Turkmenistana. Dis...kand. polit. nauk. M.: 2002. - 172 s; Aksenov D. $\mathrm{V}$. Sentral'noaziatskiy makroregion $\mathrm{v}$ novoy sisteme mejdunarodnix otnosheniy. Dis...kand. polit. nauk. M.: 2000. 157 s; Jumali R. Geopolitika Sentral'noy Azii. - Almati: 2006. - 515 s. Djamieva G.N. Istoriya stanovlniya i razvitiya Turkmenistana kak neytral'nogo gosudarstva (1995-2015 gg.). Avtoref...kand. ist. nauk. Dushanbe. 2018. - 25 s; Nizomov X. Mustaqillik yillarida O‘zbekiston va Tojikiston Respublikalari o'rtasidagi madaniy aloqalar (1991- 2007 yillar). Tarix fan. nom. dis. ... avtoref. Toshkent, 2005. - 24 b; Ziyomov N. Rol' Uzbekistana $\quad \mathrm{V}$ razvitii mejgosudarstvennogo, ekonomicheskogo i kul'turnogo sotrudnichestva stran Sentral'noy Azii (1991-2001 gg.). Dis. ... kand. ist. nauk. Tashkent, 2002. - S. 133-149.
6. Sarieva L.S. Ukreplenie dvustoronnego sotrudnichestva Kazaxstana i Uzbekistana kak faktor obespecheniya stabil'nosti i razvitiya Sentral'noaziatskogo regiona. // Aktual'ni problemi yekonomiki №10(184), 2016. S.17-22. [Elektron resurs].

7. “Yangi O‘zbekiston” gazetasi 2020 yil 5 noyabr', 212-son.

8. O’zbekiston Respublikasining Tashqi siyosiy faoliyati Konsepsiyasi. 2012 yil 10 sentyabrdagi O`RQ - 330-sonli O‘zbekiston Respublikasi Qonuni bilan tasdiqlangan // O‘zbekiston Respublikasi Oliy Majlisi palatalarining Axborotnomasi. 2012/№9/1(1437). - B.13.

9. O'zbekiston Respublikasi davlat statistika qo'mitasi joriy arxivi (O‘zR DSQ JA). 2013 - 2017 (yanv-sent) yillar davomida O'zbekiston Respublikasi va Turkmaniston davlati o'rtasida tashqi savdo aylanmasi haqida ma'lumot. 1 varaq.

10. O'zbekiston Respublikasi davlat statistika qo'mitasi joriy arxivi (O‘zR DSQ JA). Respublika bo'yicha faoliyat ko'rsatayotgan Turkmaniston hamkorligida O'zbekistonda tashkil topgan qo'shma korxonalar ro'yxati. 01.10.2017 y. holatiga. 2 - varaq.

11. Xalq so'zi, 2017 yil 5 sentyabr'.

12. Xalq so'zi. 2018 yil 10 mart.

13. Xalq so'zi. - 2018. - 16 mart.

14. Xalq so'zi. - 2018 yil - 14 mart.

15. Xalq so'zi. - 2018. -24 apr.

16. Xalq so'zi. 2018 yil 18 avgust.

17. Xalq so'zi. - 2019. - 16 aprel'.

18. Xalq so'zi. 2019 yil 30 noyabr'.

19. Xalq so'zi. 2019 yil 29 noyabr'.

20. http://kun.uz/news/2017/05/21/savkatmirzieev-va-gurbanguli-berdimuhamedov- 
imzolagan-uzzatlar-nimalardan-iborat

(22.05. 2017).

21. http://kun.uz/news/2017/04/17/dusanbeda-

uzbekiston-masulotlari-kurgazmasi-bulib-

utmokda (02.10.2017).

22. https://kun.uz/91055693

23. https://uzanalytics.com/xal

24. 24.https://uzanalytics.com/iqtisodi\%Do\%B5

t/4448/?fbclid=IwARoWFxZDifzTV-

stGWZG81Yq8IEdjJnthNHx9CHKOtHRhC

w2eQ9HLe8uQPQ (26.04.2019). 